\title{
SCENARIO APPROACH TO AGRICULTURAL DEVELOPMENT IN AZERBAIJAN
}

\author{
Nadjiba Gabilqizi Hajiyeva \\ Baku State University, Azerbaijan
}

\begin{abstract}
The purpose of this paper is to substantiate the optimal scenario to develop agriculture for the effective diversification of the Azerbaijani economy. By constructing an intersectoral balance model and using regression analysis, we propose the approach for determining optimal agriculture development scenarios taking into account the current development trends of the industry: innovative, inertial, and balanced. Using the balance model helps to account for the cause-and-effect relationships between the indicators of the development of all sectors of the Azerbaijani economy and comprehensively assess the impact of agricultural development on the diversification of the national economy. In contrast to the classical balance model, the modified model proposed in our article provides possibilities to assess not just the production potential of industries but also their contribution to the formation of the country's GDP and diversification of the economy on the way to neutralizing oil dependence.
\end{abstract}

Keywords: development scenarios, balance model, Azerbaijan, economic diversification, agriculture, GDP

DOI: http://dx.doi.org/10.15549/jeecar.v8i4.835

\section{INTRODUCTION}

Crucial features of the development of the modern economy in Azerbaijan

A feature of the modern economy of Azerbaijan is its considerable dependence on the oil industry, which provides a significant part of the Republic's GDP production but with a low level of employment in the energy sector of the economy. The government has reorientated the priorities for building the potential of Azerbaijan's energy sector; that is, hydrocarbons remain an important resource-forming factor for the country's state budget and foreign trade relations. More than $90 \%$ of Azerbaijan's exports are oil and gas, and $2 / 3$ rds of the country's state budget revenues come from crude oil (Ministry of Finance Republic of Azerbaijan, 2021). The long-term development of the oil monoprofile of the country's economy has caused a steady decline in the level of competitiveness of Azerbaijani producers and products in the domestic and international markets, accompanied by the so-called "Dutch disease" (Pettinger, 2017). In the case of Azerbaijan, the long-term dependence of the national economy on the energy sector over the past 20 years has led to epochal economic and political centralization and constantly increasing corruption in the country due to the redistribution of oil capital. In addition, the low level of diversification of the Azerbaijan economy and a sharp decline in the level of oil prices since 2014 has been leading the country to a multifaceted crisis in which low oil prices provoke a significant 
economic contraction, the devaluation of the manat, rising inflation, and a decrease in household income and the quality of life in the country. At the same time, the current trends in climate change and the reorientation of numerous countries towards the development of green energy cause some to predict an additional destructive influence on Azerbaijan's economy (BP, 2020). The consequences of the COVID-19 pandemic also have led to a sharp decline in oil prices in the global energy market. Within the framework of OPEC, Azerbaijan agreed to cut oil production, resulting in a decrease in GDP growth at the beginning of 2021 of $4.3 \%$. (O'Byrne, 2021). For Azerbaijan, the consequence of these trends would be a continued reduction in state budget revenues, and in the absence of an attempt to effectively diversify the national economy, we can soon foresee an economic depression or even a collapse. Considering, then, the potential collapse of the country's economy and the modern trends of its development, there is an urgent need to revive Azerbaijan's agricultural sector.

\section{Agricultural development as a factor in economic diversification}

The tendencies of the modern development of the country's national economy have a detrimental effect on the population's standard of living. As evidenced by the results of many studies in the current conditions in the coming decades, even without taking into account the destructive impact of the pandemic, it will not be possible to achieve the standard of living that was experienced, for example, in 2008-2014 (Baku Research Institute, 2020; Yildirim \& Arifli, 2021). Because of this, the strategy for supporting the national economy should be based on the conceptual approach of comparative advantage, implying that economic diversification should ensure the priority development of the most profitable sectors of the economy and rapidly expanding industries. (Baku Research Institute, 2020). For Azerbaijan, one such industry is agriculture, which has a considerable export and investment potential and can quickly provide a high-profit level with an effective development strategy.

The modern agro-industrial complex is one of the main sectors of the national economy of Azerbaijan and also has decisive importance on the natural, economic, human, and ethnocultural potential of the Republic. Until 2000, agriculture accounted for more than $16 \%$ of the country's GDP (State Statistical Committee of the Republic of Azerbaijan, 2021). However, the share of the agricultural sector has been shrinking significantly in the structure of the national economy over the past 20 years. As of the beginning of 2020, the agro-industrial complex was only 5.7 of the country's GDP, while almost half of the country's population (47\%) lives in rural areas, and 39\% of the employed population is involved in the processing of agricultural products (State Statistical Committee of the Republic of Azerbaijan, 2021).

The government of Azerbaijan realizes the need to develop a sustainable agro-industrial complex and, due to the existing institutional and macroeconomic features of the economic system caused by oil dependence, have implemented some reforms in the country aimed at improving the provision of a food safety system and encouraging agricultural producers to incorporate new technologies in the industry (World Bank Group, 2021). It should be noted that this reform was aimed primarily at achieving a short-term result to neutralize the risk of food shortages and food price fluctuations that Azerbaijan will face soon due to the variance of oil prices on the world market (Olayungbo, 2021). In addition, the problem of global warming and climate change also applies to Azerbaijan, particularly in terms of reducing groundwater reserves. The country contains no more than $10 \%$ of the total volume of sweet-water in the Caucasus (Gulaliyev, Ibrahimov \& Nabiyev, 2016), while over the past almost 20 years, the importance of consumption of sweet-water in agriculture has increased by more than $75 \%$ (European Environment Agency, 2019). The deterioration of the conditions for the development of agriculture is exacerbated by a decrease in the amount of arable land due to landslides, floods, chemical pollution, oil spills, etc. (RAE Aliyev ZH, 2018). Given this, it seems necessary that, not short-term, but results-oriented strategic development of the agricultural sector is needed. We have attempted in this paper to determine the most effective strategy for developing agriculture, ensuring its competitiveness and profitability, reducing the oil dependence of 
the Azerbaijani economy, and achieving its adequate diversification.

\section{LITERATURE REVIEW}

The scenario approach in studying the development of branches of the national and global economy is one of the most widespread and demanded scientific methods (Hong \& Thuy, 2021; Durman et al., 2021; Gerasimov et al., 2020; Fleming et al., 2021; Vasiljeva et al., 2020). The widespread use of the scenario approach studying the agro-industrial complex is due to the possibility of choosing the most suitable management alternative at various stages of development. Scenario analysis provides the opportunity to analyze the current situation from multiple points of view and assess the consequences and risks when choosing one or another strategic direction of development (Hong \& Thuy, 2021; Tarasenko, Korolko \& Belyavska, 2009). The ability to predict development trends is a vital management advantage in an ever-changing business environment. The scenario approach gives a possibility to focus attention on the likelihood of certain events characteristic of a market economy at its present stage. This allows for achieving flexibility in making strategic and tactical management decisions and alternatives for planning activities, which is achieved by aggregating various data on the state of agricultural enterprises or the industry as a whole and accounting for the system of qualitative and quantitative factors of influence of the external environment of the industry, etc. (Vasiljeva et al., 2020; Hajipour et al., 2021; Shapran \& Britchenko, 2021).

The analysis of scientific literature has shown that the overwhelming majority of economists studied mainly the dynamics of agricultural development to determine:

- A pessimistic scenario (reflects the worstcase agricultural development: all factors negatively affect the change in the state of agricultural enterprises) (Gerasimov et al., 2020).

- The optimistic scenario (shows the most progressive development option due to the positive influence of factors on the financial and economic condition of agricultural companies) (Gerasimov et al., 2020).
- A realistic scenario (reflects the combination of the impact of "positive" and "negative" events for the development of the agricultural sector (Ragulina et al., 2019; Fleming et al., 2021; Bezpartochnyi, Britchenko \& Bezpartochna, 2021).

The scenarios considered in the methodology for studying the agricultural sector are universal, applicable to the development of crisis conditions, a recovery from the crisis, as well as in a period of prosperity. Within the framework of the scenario approach, many scientists also use L, U, V-shaped development scenarios (Hajipour et al., 2021) to model ways to overcome the crisis in the agro-industrial complex, depending on the degree and duration of crisis manifestations. The presented methodology of scenario analysis in the study of agriculture has been used in most cases to determine development trends and dynamic characteristics of agricultural enterprises for the industry as a whole (Fleming et al., 2021; Onegina et al., 2020). But the scenario approach in these scientific works was used separately for the agricultural sector or a group of agricultural enterprises to determine the prospects for the country's food security (Laborde, Martin \& Vos, 2021) and rarely with an assessment of the nature of the impact to the national economy (Frija et al., 2021). This approach does not allow to reliably determine an effective scenario for the development of agriculture within the framework of economic diversification and to determine the participation of the agro-industrial complex as an alternative vector of economic growth.

The development of agriculture in different economies also has other meanings. For developed countries, the sustainability of the agro-industrial sector is more important as a factor in food security (Frija et al., 2021), largely because the added value produced in agriculture is significantly lower than in other sectors of the economy (Kyrkilis \& Simeon, 2015). This industry has never been seen as a fundamental factor for extensive economic growth in a developed market (Nowak, Kobiałka \& Krukowski, 2021).

On the other hand, if we talk about a developing resource economy such as Azerbaijan, the sustainability and effective 
development of agriculture are of crucial importance, not just as a factor in food security (Huseynov, 2020) but also as a factor supporting the country's economic growth in the face of a significant decline in the price of crude oil and of the active development of a worldwide green economy (HampelMilagrosa et al., 2020). Within the framework of these restrictions, scientists have focused not on the study of development dynamics scenarios but on the development strategies of agricultural enterprises (Szabó, 2015; Guliyeva et al., 2021). This direction of scenario modeling characterizes several types of scenarios that distinguish the role of innovation and science in the development of the agricultural sector:

- innovative, scientists insist on the relevance of the implementation with which to assess and model the development of the agricultural industry (Fleming et al., 2021; Oliveira et al., 2019; Kuzin et al., 2018);

- inertial or conservative, which implies the development of the industry through extensive growth without using innovations (Kuzin et al., 2018);

- target (accelerated), according to which, ensuring sustainable development, the growth rates of the industry are accelerated based on the implementation of an innovative scenario (Kuzin et al., 2018).

Because the resource orientation of the development of the Azerbaijani economy has formed threats to the economic and food security of the country, as indicated in the introduction, agriculture should develop according to a scenario that ensures the sustainability of the country's food security and economic growth in the country as well, achieving it as soon as possible. Therefore, it is advisable to develop a methodological approach to the scenario of balanced development of agriculture, which scientists in the scientific literature did not consider we have studied (Fleming et al., 2021; Oliveira et al., 2019; Kuzin et al., 2018; Gerasimov et al., 2020; Frija et al., 2020). A balanced development scenario assumes the use of intensive and extensive growth paths, a moderate increase in the role of science and innovation in creating the industry's GDP and taking into account not only the specifics of the development of the economy of a particular country but also the complementary participation of each of the main sectors of the economy, including agriculture. This approach will ensure the most effective diversification of the economy, reducing the level of oil revenues and increasing the economy's non-oil sector in the production of Azerbaijan's GDP.

\section{METHODOLOGY}

To determine the most effective scenario for the development of agriculture in Azerbaijan to ensure the diversification of the national economy, we used the balance model of V. Leontiev (Sancho, 2019) and the regression analysis method. The use of the balance model allows reflecting the interdependencies between sectors of the economy (mutual consumption of goods and services between industries) and the volume of the final product-oriented towards internal or external consumption. The balance model makes it possible to represent the national economy as an open system with internal interconnections, which most accurately reflects the present state of the modeled object and the level of economic diversification.

The classical balance model has the form (Sancho, 2019):

$$
\left\{\begin{array}{c}
x_{1}=e_{11} \times x_{1}+e_{12} \times x_{2}+\cdots+e_{1 n} \times x_{n}+a_{1} \\
x_{2}=e_{21} \times x_{1}+e_{22} \times x_{2}+\cdots+e_{2 n} \times x_{n}+a_{2} \\
\cdots \cdots \cdots \\
x_{n}=e_{n 1} \times x_{1}+e_{n 2} \times x_{2}+\cdots+e_{n n} \times x_{n}+a_{n}
\end{array}\right.
$$

where $x_{i}$ - production volume of the $i$-th industry;

$e_{i j}$ - the volume of products produced by the $i$-th industry, used to create a unit of output by the $j$-th industry;

$a_{i}$ - the volume of final products produced by the $i$-th industry.

However, constructing a classical balance model for the Azerbaijani economy is impossible due to the lack of statistical data on consumption by one industry of goods and services produced by another sector. To solve this problem, we determined the indicators of the mutual flows of goods and services between sectors of the national economy using the regression analysis method and the Granger causality test (Rajbhandari \& Zhang, 
2021). For this, we used chain growth rates of GDP production in all sectors of the Azerbaijani economy (compared to the same quarter of the previous year). Growth rates were calculated based on GDP values in dollar terms for 2005 to the first quarter of 2021 (State Statistical Committee of the Republic of Azerbaijan, 2021)_.The GDP growth rates, expressed as index variables, were used when constructing regression models in this study.

The classical balance model makes it possible to simulate production volumes by industry, which will make it possible to draw conclusions and opportunities for diversifying the national economy. But production volumes do not fully reflect economic development and the effectiveness of economic diversification (Sancho, 2019) because the growth in production volumes of some industries can be triggered by increasing the level of intermediate consumption by other industries, which neutralizes the positive impact on the dynamics of GDP (Viet, 2009). As a result, the coefficients of the classical balance model (Formula 1) underwent the following modifications to develop an intersectoral balance model:

- the indicator $x_{i}$ meant the volume of GDP produced by the $i$-th industry.

- $e_{i j}$ - Coefficients of multivariate regression models reflecting the influence of the GDP growth rates produced by the $i$-th industry on the GDP growth rates of the $j$-th industry.

According to the classical model, these indicators reflect the contribution of the i-th industry to the development of the $\mathrm{j}$-th. Unlike the classical one, they do not remember the production process but do remember final consumption. In essence, these indicators correlate with the $\boldsymbol{a}_{i}$ indicators of the classical model. But in the classical model, these are static indicators and do not affect the development of other industries. In the modified model $e_{i j,}$, these are indicators that affect the development of other industries;

- $a_{i}$ - free members of multivariate regression models reflecting the influence of the GDP growth rates produced in the $i$-th industry on the GDP growth rates of the $j$-th industry.

The indicators $e_{i j}, a_{i}$ of the modified model were determined by constructing multivariate regression models.

We used as variables in the models the indicators of the GDP growth rates produced by the sectors of the Azerbaijani economy. The dependent and independent variables were swapped depending on the industry whose GDP is being modeled. Stationarity was verified using the Dickey-Fuller extended test (Rajbhandari \& Zhang, 2021). The proven stationary nature of the data allowed the Granger causality test to be applied. The results of the Granger test allowed us to establish the direction of the cause-and-effect relationships and the regression analysis - the nature of the connections. For modeling purposes (building regression models, checking for stationarity, for causality), the EViews10 program was used.

We built regression models to assess the effectiveness of scenarios for the development of agriculture. The rate of growth of GDP produced in the industry was used as a dependent variable. The independent variable was the growth rate of GDP in the Professional, Scientific and Technical Activities industry. Relationships between the variables were estimated using a time lag of 1-5 periods (quarters). Innovative goods and services used in agriculture can be represented by raw materials, machinery, technologies, fertilizers, appropriate personnel, or decision-making technologies. But the source of such goods and services is the Professional, Scientific and Technical Activities industry.

Checking the models using the Chow test in the EViews 10 program showed the presence of structural shifts, reflecting the different nature of the impact on the industry's GDP of Professional, Scientific and Technical Activities growth rates on the development of the agricultural sector, depending on the level of the first indicator. We used the t-criterion for two independent samples to determine the ranges of values of the indicator of the GDP growth rate in Professional, Scientific, and Technical Activities, reflecting structural changes.

\section{RESULTS}

Implementing the described methodology to determine the most effective scenario for developing the agricultural sector in 
Azerbaijan was possible due to the observance of the following requirements for the study sample. First, the stationarity of the time series is a necessary criterion for applying the Granger test (Rajbhandari \&
Zhang, 2021). The test results are presented in Table 1.

Table1: The estimates stationarity of sectoral GDP growth rates in Azerbaijan for 2005 - 1 quarter 2021 using the Dickey-Fuller method

\begin{tabular}{|c|c|c|}
\hline Indicators & Specification* & Prob.** \\
\hline $\begin{array}{l}\text { GDP growth rate in the industry Agriculture, forestry and fishing } \\
\text { (GDPag) }\end{array}$ & $I, 0$ & 0.0000 \\
\hline GDP growth rate in the industry Mining (GDPmin) & $I, 1$ & 0.0037 \\
\hline GDP growth rate in the industry Manufacturing (GDPman) & $I, 1$ & 0.0013 \\
\hline $\begin{array}{l}\text { GDP growth rate in the industry Electricity, gas and steam production, } \\
\text { distribution and supply (GDPel) }\end{array}$ & $I, O$ & 0.0003 \\
\hline $\begin{array}{l}\text { GDP growth rate in the industry Water supply, waste treatment and } \\
\text { disposal (GDPwat) }\end{array}$ & $I, 0$ & 0.0060 \\
\hline GDP growth rate in the industry Construction (GDPcons) & $I, 1$ & 0.0047 \\
\hline GDP growth rate in the industry Trade (GDPtr) & $I, 1$ & 0.0013 \\
\hline $\begin{array}{l}\text { GDP growth rate in the industry Transportation and storage } \\
\text { (GDPtransp) }\end{array}$ & $I, 1$ & 0.0100 \\
\hline $\begin{array}{l}\text { GDP growth rate in the industry Accommodation and food service } \\
\text { activities (GDPfood) }\end{array}$ & I, 1 & 0.0007 \\
\hline $\begin{array}{l}\text { GDP growth rate in the industry Information and communication } \\
\text { (GDPinf) }\end{array}$ & I, 1 & 0.0024 \\
\hline $\begin{array}{l}\text { GDP growth rate in the industry Financial and insurance activities } \\
\text { (GDPfin) }\end{array}$ & $I, O$ & 0.0066 \\
\hline GDP growth rate in the industry Real estate activities (GDPest) & $I, 0$ & 0.0077 \\
\hline $\begin{array}{l}\text { GDP growth rate in the industry Professional, scientific and technical } \\
\text { activities (GDPscien) }\end{array}$ & $I, 0$ & 0.0010 \\
\hline $\begin{array}{l}\text { GDP growth rate in the industry Administrative and support service } \\
\text { activities (GDPadm) }\end{array}$ & $I, 0$ & 0.0111 \\
\hline $\begin{array}{l}\text { GDP growth rate in the industry Public administration and defence, } \\
\text { social security (GDPsecur) }\end{array}$ & I, 1 & 0.0050 \\
\hline GDP growth rate in the industry Education (GDPed) & $I, 0$ & 0.0181 \\
\hline $\begin{array}{l}\text { GDP growth rate in the industry Human health and social work } \\
\text { activities (GDPheal) }\end{array}$ & $I, O$ & 0.0061 \\
\hline $\begin{array}{l}\text { GDP growth rate in the industry Arts, entertainment and recreation } \\
\text { (GDPart) }\end{array}$ & $I, 0$ & 0.0130 \\
\hline GDP growth rate in the industry Other service activities (GDPot) & $I, O$ & 0.0185 \\
\hline
\end{tabular}

* - I (Intercept) - specification of a time series relative to a constant; 0 - level; 1 - 1st-row difference;

** - Prob. - the probability of non-stationary of a time series at a level of significance $p=0.05$.

Source: Authors' finding

For all indicators, the probability that the time series is non-stationary does not exceed 0.05 , proving the stationarity of time series and the possibility of using them to test cause-and-effect relationships.

Second, the normal distribution of variables is a necessary condition for constructing regression models. The probabilities evidence the normal distribution of variables to accept the normal distribution (Normality Test) hypothesis, exceeding 0.05 for all indicators (IHS Global, 2021). 
Table 2: Values of indicators of the intersectoral balance model for Azerbaijan

\begin{tabular}{|c|c|c|c|c|c|c|c|c|c|c|c|c|c|c|c|c|c|c|c|}
\hline Indicators & 今ే & $\begin{array}{l}\text { 怘 } \\
\text { 今 }\end{array}$ & 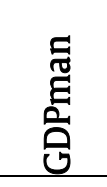 & $\begin{array}{l}\bar{\Xi} \\
\text { 今े }\end{array}$ & 䓌 & 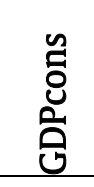 & 志 & 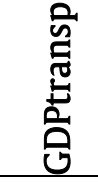 & 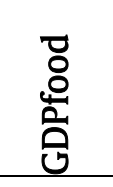 & 嵓 & $\begin{array}{l}\text { 员 } \\
\text { 号 }\end{array}$ & $\begin{array}{l}\text { पे } \\
\text { 仓े }\end{array}$ & 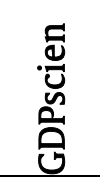 & $\begin{array}{l}\text { 몸 } \\
\text { 苗 } \\
0\end{array}$ & 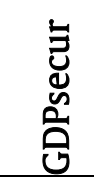 & 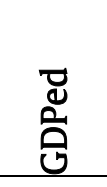 & 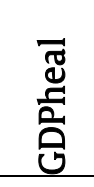 & 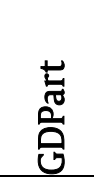 & $\begin{array}{l}\text { 음 } \\
0 \\
0\end{array}$ \\
\hline & \multicolumn{19}{|c|}{$e_{i j}$} \\
\hline GDPag & - & - & 0.02 & - & - & - & 0.02 & 0.04 & 0.07 & - & - & - & - & - & - & - & - & - & - \\
\hline GDPmin & -0.11 & - & 0.36 & 0.66 & - & 0.38 & 0.54 & 0.40 & 0.13 & 0.18 & 0.22 & 0.09 & 0.12 & 0.14 & 0.20 & 0.17 & 0.22 & - & 0.07 \\
\hline GDPman & 0.49 & 0.61 & - & - & - & - & 0.43 & 0.36 & 0.44 & 0.32 & - & - & - & - & - & - & - & - & - \\
\hline GDPel & - & - & 0.26 & - & - & - & - & - & - & - & - & - & - & - & - & - & - & - & - \\
\hline GDPwat & 0.31 & - & - & - & - & - & - & - & - & - & - & - & - & - & - & - & - & - & - \\
\hline GDPcons & - & 0.11 & - & - & - & - & - & - & - & - & - & - & - & - & - & - & - & - & - \\
\hline GDPtr & - & - & - & - & - & - & - & - & 0.17 & - & - & - & - & - & - & - & - & - & - \\
\hline GDPtransp & - & - & - & - & - & - & - & - & - & - & - & - & - & - & - & - & - & - & 0.18 \\
\hline GDPfood & - & - & - & - & - & - & - & - & - & - & - & - & - & - & - & - & - & - & - \\
\hline GDPinf & - & - & 0.33 & - & - & - & - & - & - & - & - & - & 0.46 & 0.18 & 0.35 & 0.27 & - & - & - \\
\hline GDPfin & 0.22 & 0.13 & 0.20 & 0.08 & - & - & - & - & - & - & - & - & - & - & - & - & - & - & - \\
\hline GDPest & - & - & - & - & - & - & - & - & - & - & 0.12 & - & - & - & - & - & - & - & - \\
\hline GDPscien & 0.37 & 0.42 & 0.61 & 0.28 & - & - & - & - & - & 0.57 & - & - & - & - & - & 0.43 & - & - & - \\
\hline GDPadm & - & - & - & - & - & - & - & 0.05 & 0.10 & 0.11 & 0.11 & - & 0.20 & - & - & 0.32 & - & 0.16 & - \\
\hline GDPsecur & - & - & - & - & - & - & - & - & - & - & - & - & - & 0.37 & - & - & - & - & - \\
\hline GDPed & - & - & 0.31 & - & - & - & - & - & - & 0.40 & - & - & 0.63 & - & - & - & 0.84 & - & - \\
\hline GDPheal & - & - & - & - & - & - & - & - & - & - & - & - & - & - & - & - & - & - & - \\
\hline GDPart & - & - & - & - & - & - & - & - & - & - & - & - & - & - & - & - & - & - & - \\
\hline GDPot & - & - & - & - & - & - & - & - & 0.08 & - & - & 0.12 & - & - & - & - & - & - & - \\
\hline$a_{i}$ & -0.27 & -0.63 & -1.01 & 0.16 & - & 0.66 & 0.20 & 0.33 & -0.56 & -0.57 & 0.71 & 0.84 & -0.40 & 0.34 & 0.67 & -0.09 & 0.22 & 0.88 & 0.81 \\
\hline
\end{tabular}

"-»: according to the results of the Granger test, no statistically significant effect of the $i$-th indicator on the $j$-th

Source: Authors' finding 
The Granger test made it possible to establish statistically significant causal relationships between indicators of the development of economic sectors, which appear without a time lag. The statistical significance of the test results was confirmed, accepting the hypothesis of the non-statistical relevance of the relationship (not exceeding 0.05) (Rajbhandari \& Zhang, 2021). The statistically significant (at a significance level of $95 \%$ ) relationships between the growth rates of GDP production by economy sector are shown in Table. 2.

The Student's criterion confirmed the statistical significance of these indicators. Empirical values of the criterion $(|2.83|-|5.06|)$ exceeded the critical 2.0. The adequacy of the constructed regression models was evidenced using the F-statistic, the empirical values of which were 18.93-47.16 with critical values 2.13-4.0 (Cunningham, Weathington \& Pittenger, 2013). The critical values of the criteria we indicated using a significance level of $p=0.05$. The adequacy of the regression modification was confirmed by the Ramsey Test, the value of which was $(0.52-0.82)>0.05$ (IHS Global, 2021). The residuals of the constructed models corresponded to the normal distribution (Normality Test $=[0.66 ; 0.80]$ ).

Taking into account specific correlation coefficients given in Table 2, we built an intersectoral balance model of Azerbaijan (Formula 2):

$$
\left\{\begin{array}{c}
\text { GDPag }=-0.11 \times \text { GDPmin }+0.49 \times \text { GDPman }+0.31 \times \text { GDPwat }+ \\
0.22 \times \text { GDPfin }++0.37 \times \text { GDPscien }-0.27 \\
\text { GDPmin }=0.61 \times \text { GDPman }+0.11 \times \text { GDPcons }+0.13 \times \text { GDPfin }+ \\
+0.42 \times \text { GDPscien }-0.63 \\
\text { GDPman }=0.82 \times \text { GDPag }+0.36 \times \text { GDPmin }+0.26 \times \text { GDPel }+ \\
+0.33 \times \text { GDPinf }+0.20 \times \text { GDPfin }+ \\
+0.61 \times \text { GDPscien }+0.31 \times \text { GDPed }-1.87 \\
\text { GDPel }=0.66 \times \text { GDPmin }+0.08 \times \text { GDPfin }+0.28 \times \text { GDPscien }+0.16 \\
\text { GDPcons }=0.38 \times \text { GDPmin }+0.66 \\
\text { GDPtr }=0.37 \times \text { GDPag }+0.54 \times \text { GDPmin }+0.43 \times \text { GDPman }-0.18 \\
\text { GDPtransp }=0.29 \times \text { GDPag }+0.40 \times \text { GDPmin }+0.36 \times \text { GDPman }+ \\
+0.05 \times \text { GDPadm }+0.06 \\
\text { GDPfood }=0.91 \times \text { GDPag }+0.13 \times \text { GDPmin }+0.44 \times \text { GDPman }+ \\
+0.17 \times \text { GDPtr }+0.10 \times \text { GDPadm }+0.08 \times \text { GDPot }-1.46 \\
\text { GDPinf }=0.18 \times \text { GDPmin }+0.32 \times \text { GDPman }+0.57 \times \text { GDPscien }+ \\
+0.11 \times \text { GDPadm }+0.40 \times \text { GDPed }-0.57 \\
\text { GDPfin }=0.22 \times \text { GDPmin }+0.12 \times \text { GDPest }+0.11 \times \text { GDPadm }+0.71 \\
\text { GDPest }=0.09 \times \text { GDPmin }+0.12 \times \text { GDPot }+0.84 \\
\text { GDPscien }=0.12 \times \text { GDPmin }+0.46 \times \text { GDPinf }+0.20 \times \text { GDPadm }+ \\
+0.63 \times \text { GDPed }-0.40 \\
\text { GDPadm }=0.14 \times \text { GDPmin }+0.18 \times \text { GDPinf }+0.37 \times \text { GDPsecur }+0.34 \\
\text { GDPsecur }=0.20 \times \text { GDPmin }+0.35 \times \text { GDPinf }+0.67 \\
\text { GDPed }=0.17 \times \text { GDPmin }+0.27 \times \text { GDPinf }+0.43 \times \text { GDPscien }+ \\
+0.32 \times \text { GDPadm }-0.09 \\
\text { GDPheal }=0.22 \times \text { GDPmin }+0.84 \times \text { GDPed }+0.22 \\
\text { GDPart }=0.16 \times \text { GDPadm }+0.88 \\
\text { GDPot }=0.07 \times \text { GDPmin }+0.18 \times \text { GDPtransp }+0.81
\end{array}\right.
$$

The presented intersectoral balance sheet testifies that the growth of mineral extraction impacts the development of industries and services positively: Manufacturing; Electricity, Gas and Steam Production, Distribution and Supply; Construction; Trade; Transportation and
Storage; Accommodation and Food Service Activities; Information and Communication; Financial and Insurance Activities; Real Estate Activities; Professional, Scientific and Technical Activities; Administrative and Support Service Activities; Public Administration and Defense, 
Social Security; Education; Human Health and Social Work Activities. That growth, however, negatively affects the development of agriculture in Azerbaijan.

Regression models for assessing the impact of
Professional, Scientific and Technical Activities on the agricultural sector have shown the presence of structural shifts (Chow Test Prob 0.02-0.04 (<0.05)) (IHS Global, 2021). Models of the influence of the GDPscien indicator on the GDPag we described using functions (Fig. 1).

\begin{tabular}{|c|c|c|c|c|}
\hline \multicolumn{2}{|l|}{ Model } & $\rightarrow \begin{array}{c}\text { Range of } \\
\text { values } \\
\text { GDPscien }\end{array}$ & $\rightarrow \quad \begin{array}{c}\text { Change in GDPag with an } \\
\text { increase in GDPscien by } 1 \text { p.p. }\end{array}$ & $\begin{array}{l}\text { Indicators of the statistical } \\
\text { significance in the model }\end{array}$ \\
\hline \multicolumn{2}{|l|}{$\downarrow$} & $\downarrow$ & $\downarrow$ & $\downarrow$ \\
\hline $\begin{array}{l}\text { GDPag }=1.678 \times \\
\times G D P \operatorname{Scien}(-3)+ \\
-0.665\end{array}$ & $\underset{(3)}{\text { Formula }}$ & {$[0 ; 1.357]$} & Average change +1.74 p.p. & $\begin{array}{c}F \text {-criterion }=28.33 ; \\
t \text {-criterion }(G D P s c i e n)=4.27 \\
\text { Ramsey Test }=0.62 ; \\
\text { Normality Test }=0.89\end{array}$ \\
\hline \multicolumn{2}{|l|}{$\downarrow$} & $\downarrow$ & $\downarrow$ & $\downarrow$ \\
\hline $\begin{array}{l}G D P a g=-1.043 \times \\
\times G D P \operatorname{scien}(-3)^{2}+ \\
+4.946 \times \\
\times G D P \operatorname{scien}(-3)+ \\
-3.424\end{array}$ & $\underset{(4)}{\text { Formula }}$ & $\geq 1.404$ & $\begin{array}{l}\text { 1) Maximum growth }+2.81 \text { p.p } \text {; } \\
\text { 2) at } G D P \text { scien } \rightarrow 2.372, \\
\Delta G D P a g \rightarrow 0 ; \\
\text { 3) at } G D P \text { scien }>2.372-\mathrm{a} \\
\text { decrease in the GDPscien } \\
\text { indicator }\end{array}$ & $\begin{array}{c}F \text {-criterion }=19,41 ; \\
t \text {-criterion }\left(G D P s c i e n^{2}\right)=-3.62 ; \\
t \text {-criterion }(G D P s c i e n)=3.15 ; \\
\text { Ramsey Test }=0.51 ; \\
\text { Normality Test }=0.38\end{array}$ \\
\hline
\end{tabular}

F-criterion, $t$-criterion - empirical values of the criteria

Figure 1: Regression models to assess the impact of the development of Professional, scientific and technical activities on the agricultural sector of Azerbaijan

Source: Authors' finding

The excess of the empirical F- and t-criterion values over the critical values of 4.17 and 2.04 , respectively, for model (formula 3 ), 3.80 and 2.16 for model (formula 4) (Cunningham, Weathington \& Pittenger, 2013); Ramsey Test> 0.05 and Normality Test> 0.05 indicate the adequacy of the presented regression models (IHS Global, 2021).

\section{DISCUSSION AND CONCLUSION}

The developed intersectoral balance model of Azerbaijan made it possible to empirically substantiate the complementary nature of the interaction of mining with the prevailing number of sectors of the national economy. Meanwhile, as shown by the results of our study, mining hurts the functioning of agricultural enterprises, primarily due to the deterioration of the land fund of arable land in the agricultural sector.

The stimulants for the development of the agricultural sector are:

- Manufacturing. As part of the industry, the machine-building industry provides fixed agricultural assets; chemical - fertilizers; food, light, pulp, and paper - create the prerequisites for the development of the sector by increasing demand for products.

- Water supply, waste treatment, and disposal - ensuring the functioning of land irrigation systems and watering places for animals.

- Financial and insurance activities - providing cost-effective industry financing and insurance programs. This is very important given the high level of industry risks associated with the threat of climate change.

- Professional, scientific and technical activities - creates conditions for the implementation of an innovative growth model for the agricultural industry, increasing its efficiency through the use of more efficient products in Manufacturing, as well as through the introduction of more efficient technologies for organizing internal business processes and making management decisions. The development of Education is also a prerequisite for implementing an innovative development model, as it will provide the industry with highly qualified, highly productive personnel (Pirtskhalaishvili, Paresashvili \& Kulinich, 2021). But according to the results of the 
intersectoral balance model, such an influence is not statistically significant. This is due to the low technological effectiveness level of the agricultural sector in Azerbaijan at this stage of its development.

Confirmation of the need to increase the potential of the agricultural sector for the Azerbaijani economy is the fact that its development has a positive effect on Manufacturing, Trade, Transportation and Storage, Accommodation and Food Service Activities.

In general, the positive complementary nature of the influence of agriculture on other sectors indicates its importance as a factor in the adequate diversification of the country's national economy, despite the low level of created surplus-value. In addition, the intersectoral balance model makes it possible to empirically substantiate that an increase in the growth rate of agricultural GDP by 1 p.p. leads to a rise in the country's GDP by 0.011 p.p. An increase in the growth rate of GDP created in Mining by 1 p.p. leads to a rise in the country's GDP by 0.032 p.p. The significant return on agricultural development testifies to the positive effect of economic diversification in the direction of a shift in emphasis on agricultural development, compared to mining, which is stagnating in the face of falling crude oil prices in the world market and the trend of developing a green economy in the world.

Based on the study, we determined that an increase in GDP growth rates in Professional, Scientific, and Technical activities in the range [0; $135.7 \%$ ] has a directly proportional impact on the development of the Agricultural sector: an increase in GDP growth rates by 1 p.p. on average leads to a rise in GDP in Agriculture by 1.74 p.p. The GDP growth rate in Professional, Scientific and Technical Activities from $140.4 \%+1$ p.p. provide an increase of 2.81 p.p. the GDP growth rate in Agriculture. The actual growth rate of the GDP created in Professional, Scientific, and Technical Activities in Azerbaijan from 2005 to the $1 \mathrm{st}$ quarter of 2021 was in the range of $64.0-$ 168.5\%. The maximum growth rates were observed throughout 2006 and 2008 (148.1$168.5 \%)$ and sporadically during 2009-2013. After 2013, the GDP growth rate in the industry did not exceed $113.4 \%$, which is insufficient to increase agricultural growth rates as a factor in the efficiency of economic diversification for a tactical planning horizon. According to the calculations carried out based on the intersectoral balance model, we have determined that with an annual increase in GDP growth rates in Professional, Scientific and Technical Activities by $1 \mathrm{pp}$. it is possible to ensure the rise in the growth rate of agricultural GDP by 1.74 p.p. per year, which can achieve the annual growth of Azerbaijan's GDP at the level of 0.019 p.p.

The results obtained confirm the necessity and practicality of developing the agricultural industry in Azerbaijan based on an innovative scenario at the present stage and taking into account the current level of development of the industry. At the same time, the main destructive factor in developing an optimal innovative scenario for the development of the sector, as research has shown, can be the preservation of the same level of quality of human capital and labor productivity. Therefore, at the present stage of development of the national economy of Azerbaijan in the direction of neutralizing oil dependence, state policy should be based on enhancing the quality of human capital by increasing the level of the professional and sectoral structure of the population; employment of the population mainly in industry, science, services; population mobility; the middle class in the stratification structure of society; interest of community due to rational scientific knowledge and so on.

The increase in GDP growth rates in Professional, Scientific and Technical Activities should not exceed $237.2 \%$ since, according to the constructed regression models, exceeding this level will negatively affect the development of agriculture and ensure its neutralization as a factor in the effective diversification of the national economy. We can explain it by the fact that the agricultural sector is characterized by a lower level of inter-sectoral integration and significantly lower rates of development in comparison with Professional, Scientific and Technical Activities. At this stage, the scenario of balanced development of agriculture would be more effective, which implies the development of science to the optimal level (annual growth rate of $237.2 \%$ ). After that, the development of 
the agricultural industry would be possible by increasing its efficiency and expanding other sectors: Manufacturing, Water Supply, Waste Treatment and Disposal, and Financial and Insurance Activities.

Using the intersectoral balance model made it possible to consider the causal relationships between the indicators of the development of all sectors of the economy and comprehensively assess the impact of the agricultural effect on the diversification efficiency of the Azerbaijani economy, as well as to determine effective scenarios for its development. But the study results are limited to a sample of the sectors of one country; it can only apply to the peculiarities of agriculture in Azerbaijan. At the same time, the issues of the optimal structure of the intersectoral model, which ensures the most effective level of diversification of the Azerbaijani economy, remained outside the scope of our attention. Since this direction requires fundamental development, our following research will be devoted to these issues.

\section{REFERENCES}

Baku Research Institute. (2020). Azerbaijan 2030: A Vision of the Future. https://bakuresearchinstitute.org/en/azerbai jan-2030-a-vision-of-the-future/

Bezpartochnyi, M., Britchenko, I., \& Bezpartochna, O. (2021). Ensuring the financial safety of Ukrainian agricultural enterprises in the context of export products and the impact on macroeconomic indicators. VUZF Review, 6 (3), 186-195. https://doi.org/10.38188/2534-9228.21.3.20

BP. (2020). BP sets ambition for net zero by 2050 , fundamentally changing organisation to deliver https://www.bp.com/en/global/corporate/n ews-and-insights/press-releases/bernardlooney-announces-new-ambition-forbp.html

Cunningham, C.J.L., Weathington, B.L., \& Pittenger, D.J. (2013). Understanding and Conducting Research in the Health Sciences. John Wiley \& Sons, Inc. https://onlinelibrary.wiley.com/doi/pdf/10.1 002/9781118643624.app2
Durman, O., Durman, M., Topalova, E., Grytsak, L., \& Zhiliaieva, O. (2021). An economic model to assess the effectiveness of economic cooperation between Ukraine and international non-government organization. Journal of Eastern European and Central Asian Research (JEECAR), 8(1), 62-80. https://doi.org/10.15549/jeecar.v8i1.640

European Environment Agency. (2019). C3 Total water use in the Republic of Azerbaijan. https://eniseis.eionet.europa.eu/east/indicators/c32013-total-water-use-in-the-republic-ofazerbaijan

Fleming, A., Jakku, E., Fielke S., Taylor, B.M., Lacey, J., Terhorst, A., \& Stitzlein, C. (2021). Foresighting Australian digital agricultural futures: Applying responsible innovation thinking to anticipate research and development impact under different scenarios. Agricultural Systems, 190, 103120. https://doi.org/10.1016/j.agsy.2021.103120

Frija, A., Chebil, A., Mottaleb, K.A., MasonD'Croz, D., \& Dhehibi, B. (2020). Agricultural growth and sex-disaggregated employment in Africa: Future perspectives under different investment scenarios. Global Food Security, 24, 100353. https://doi.org/10.1016/j.gfs.2020.100353

Gerasimov, A. N., Gromov, E. I., Grigoryeva, O. P., Skripnichenko, Y. S., \& Kapustina, E. I. (2020). Scenario forecasting tools in the system of managerial decision-making in the agrarian economy of southern Russia. Revista Espacios, 41 (03). http://www.revistaespacios.com/a20v41n03 /20410328.html

Gulaliyev, M., Ibrahimov, S., \& Nabiyev, A. (2016). Estimated Amount of «Virtual Water» in Azerbaijan. Russian Journal of Agricultural and Socio-Economic Sciences, 56, 127-136. https://doi.org/10.18551/rjoas.2016-08.16.

Guliyeva, S., Sadigov, Y., Guliyeva, N., Isayeva, L., \& Aliyeva, S. (2021). Person-centered approach effectiveness in Human Resource Management in the agriculture of Azerbaijan. Journal of Eastern European and Central Asian Research (JEECAR), 8(2), 267- 
279.

https://doi.org/10.15549/jeecar.v8i2.713

Hajipour, V., Aminian, M., Gharaei, A., \& Jalali, S. (2021). A business retrieval model using scenario planning and analytics for life during and after the pandemic crisis. Healthcare Analytics, 1, 100004.

https://doi.org/10.1016/j.health.2021.100004

Hampel-Milagrosa, A., Haydarov, A., Anderson, K., Sibal, J., \& Ginting, E. (2020). Azerbaijan Moving Toward More Diversified, Resilient, and Inclusive Development. Asian Development Bank. http://dx.doi.org/10.22617/SGP200216-2

Hong, P. T. T., \& Thuy, N. T. T. (2021). Development scenarios for the taxi services market in Vietnam in terms of competitiveness. Journal of Eastern European and Central Asian Research (JEECAR), 8(1), 121-132. https://doi.org/10.15549/jeecar.v8i1.657

Huseynov, R. (2020). Dynamics of Multidimensional Food Security in Azerbaijan. Academic Journal of Economic Studies, Faculty of Finance, Banking and Accountancy Bucharest,"Dimitrie Cantemir" Christian University Bucharest, 6(1), 44-50.

IHS Global. (2021). EViews. User’s Guide. http://www.eviews.com/help/helpintro.htm l\#page/content/preface.html\#wwconnect_h eader

Kuzin, A.A., Medvedeva, N.A., Zadumkin, K.A., \& Vakhrusheva, V.V. (2018). Development scenarios for Russia's dairy industry. Economic and Social Changes: Facts, Trends, Forecast, 11, 6, 73-88. https://doi.org/10.15838/esc.2018.6.60.5.

Kyrkilis, D., \& Simeon, S. (2015). Greek Agriculture's Failure. The Other Face of a Failed Industrialization. From Accession to EU to the Debt Crisis. Procedia Economics and Finance, 33, 64-77

Laborde, D., Martin, W., \& Vos, R. (2021). Impacts of COVID-19 on global poverty, food security, anddiets: Insights from global model scenario analysis. Agricultural Economics, 52, 375-390

Ministry of finance Republic of Azerbaijan. (2021). Analysis of the execution of budget incomes and expenses. http://www.maliyye.gov.az/en/static/15/ana lysis-of-the-execution-of-budget-incomesand-expenses

Nowak, A., Kobiałka, A., \& Krukowski, A. (2021). Significance of Agriculture for Bioeconomy in the Member States of the European Union. Sustainability, 13, 8709. https://doi.org/10.3390/su13168709

O'Byrne, D. (2021). Azerbaijan warned of need for energy diversity. https://eurasianet.org/azerbaijan-warnedof-need-for-energy-diversity

Olayungbo, D.O. (2021). Global oil price and food prices in food importing and oil exporting developing countries: A panel ARDL analysis. Heliyon, 7, 3, e06357. https://doi.org/10.1016/j.heliyon.2021.e063 57

Oliveira, M.d.F., Gomes da Silva, F., Ferreira, S., Teixeira, M., Damásio, H., Dinis Ferreira, A., \& Gonçalves, J.M. (2019). Innovations in Sustainable Agriculture: Case Study of Lis Valley Irrigation District, Portugal. Sustainability, 11, 331. https://doi.org/10.3390/su11020331

Onegina, V., Megits, N., Antoshchenkova, V., \& Boblovskyi, O. (2020). Outcome of capital investment on labor productivity in agriculture sector of Ukraine. Journal of Eastern European and Central Asian Research (JEECAR), 7(1), 12-25. https://doi.org/10.15549/jeecar.v7i1.355

Pettinger, T. (2017). Dutch disease. https://www.economicshelp.org/blog/11977 /oil/dutch-disease/

Pirtskhalaishvili, D., Paresashvili, N., \& Kulinich, T. (2021). The gender aspects of career development and leadership in organizations. Journal of Eastern European and Central Asian Research (JEECAR), 8(2), 255 - 266. https://doi.org/10.15549/jeecar.v8i2.654

RAE Aliyev ZH. (2018). Agriculture in Azerbaijan and its Development Prospects. JOJ Sciences. https://juniperpublishers.com/jojs/pdf/JOJS. MS.ID.555572.pdf

Ragulina, Y., Shkodinsky, S, Mishchenko, V., \& Romanova, Y. (2019). Scenarios of Development of Industry 4.0 in the Conditions of Knowledge Economy's 
Formation and Their Consequences for Modern Economic Systems. In: Industry 4.0: Industrial Revolution of the 21st Century, 227-234. https://doi.org/10.1007/978-3319-94310-7_23.

Rajbhandari, A., \& Zhang, F. (2021). Does Energy Efficiency Promote Economic Growth? Evidence from a Multi-Country and MultiSector Panel Data Set. World Bank Group. https://documents1.worldbank.org/curated/ en/957991496167336779/pdf/WPS8077.pdf

Sancho, F. (2019). An Armington-Leontief model. Economic Structures, 8, 25. https://doi.org/10.1186/s40008-019-0158-y

Shapran, V., \& Britchenko, I. (2021). Financial mechanisms of ensuring the development of business under high interest rates. VUZF review, 6 (2), 16-24. https://doi.org/10.38188/2534-9228.21.2.03

State Statistical Committee of the Republic of Azerbaijan. (2021). https://www.stat.gov.az/source/agriculture/ ?lang=en

Szabó, A. (2015). SMEs and Small Farms in Agribusiness in the BSEC Region. Chişinău.

Tarasenko, I.O., Korolko, O.M., \& Belyavska, K.S. (2009). Enterprise innovative activity evaluation in the system of strategic management. Actual Problems of Economics, 9, 133-141.

Vasiljeva, M., Neskorodieva, I., Ponkratov, V., Kuznetsov, N., Ivlev, V., Ivleva, M., Maramygin, M., \& Zekiy, A. A. (2020). Predictive Model for Assessing the Impact of the COVID-19 Pandemic on the Economies of Some Eastern European Countries. J. Open Innov. Technol. Mark. Complex., 6, 92. https://doi.org/10.3390/joitmc6030092

Viet, V. Q. (2009). GDP by production approach: A general introduction with emphasis on an integrated economic data collection framework. https://unstats.un.org/unsd/China_UNSD_Pr oject/GDP\%20by\%20production\%20approach .pdf

World Bank Group. (2021). In Azerbaijan, a More Competitive Agricultural Sector Will Benefit Agribusinesses and Farmers. https://www.worldbank.org/en/news/featur e/2021/02/18/in-azerbaijan-a-more- competitive-agricultural-sector-willbenefit-agribusinesses-and-farmers

Yildirim, Z., \& Arifli, A. (2021). Oil price shocks, exchange rate and macroeconomic fluctuations in a small oil-exporting economy. Energy, 219, 119527. https://doi.org/10.1016/j.energy.2020.119527

\section{ABOUT THE AUTHOR}

Nadjiba Gabilqizi Hajiyeva, email: nadjiba_h@mail.ru

Nadjiba Gabilqizi Hajiyeva, Ph.D. in Economics, Senior lecturer at Baku State University, Azerbaijan. 